\title{
PERANCANGAN KERANGKA PENGUKURAN KINERJA BALANCED SCORECARD DENGAN METODE QUALITY FUNCTION DEPLOYMENT PADA PT. MML
}

\author{
Rudy Vernando Silalahi ${ }^{1}$, Helena Juliana Kristina ${ }^{2}$ Shelvia $^{3}$ \\ ${ }^{1,2,3}$ Program Studi Teknik Industri, Fakultas Sains dan Teknologi \\ Universitas Pelita Harapan, Tangerang \\ E-mail: rudy.silalahi@uph.edu
}

\begin{abstract}
A b s trak
PT. MML as electronic retail company was founded in 2010. This company doesn't have performance measurement that can cover the whole company performance that is needed. Moreover, the system of performance measurement is partial. The outcome of measurement is only evaluated by related manager and it doesn't involve other department manager thus improvement that is conducted, doesn't notice the other impact that is given to another department performance. On that word, designing Balanced Scorecard performance measurement framework with Quality Function Deployment method is required to framework of performance measurement as integrated strategic measurement tool for all departments. In designing that framework needs some data such as interview data, and questionnaire data which is intended to Top Manager for determining performance measures, customer and staff for determining performance driver by using type of sampling is simple random sampling. Besides, matrix of House of Quality roles to decide performance measure with its performance driver, while matrix of QFD II roles to design strategic map and diagram of cause-effect relationship. Based on simulation, the result of performance measurement for financial perspective is 3.1 (quite good), customer perspective is 3.51 (good), internal business process perspective is 4.27 (very good), learning and growth perspective is 4.33 (very good).
\end{abstract}

Keyword : Kerangka pengukuran kinerja, Balanced Scorecard, Quality Function Deployment.

\section{PENDAHULUAN}

Ketatnya persaingan bisnis saat ini semakin menuntut perusahaan untuk terus meningkatkan kinerja perusahaanya. Pengukuran kinerja mampu memberikan gambaran mengenai pencapaian hasil yang telah diraih oleh perusahaan. Selain itu juga, pengukuran kinerja mampu menggambarkan keberhasilan penerapan strategi oleh perusahaan.

Permasalahan yang terjadi pada umumnya, pengukuran kinerja perusahaan masih terfokus pada laporan keuangan perusahaan dan kepuasan pelanggan yang bersifat parsial. Alat ukur kinerja yang digunakan belum jelas dan belum menyeluruh sehingga menyulitkan pihak perusahaan untuk melakukan evaluasi kinerja. PT. MML adalah perusahaan yang bergerak di bidang retail elektronik juga mengalami permasalahan yang serupa dimana perusahaan masih melakukan pengukuran kinerja berdasarkan laporan keuangan dan laporan kesalahan pengiriman produk. Pengukuran kedua aspek ini belum mampu menyokong keberhasilan perusahaan untuk bertahan dalam persaingan. Perusahaan yang baru berdiri sejak tahun 2010 ini belum memiliki ukuran kinerja yang jelas dan mencakup keseluruhan aspek.

Pengukuran kinerja yang dilakukan pada PT. MML masih bersifat parsial. Hasil pengukuran kinerja hanya dievaluasi oleh manajer bersangkutan dan belum melibatkan manajer dari departemen lainnya sehingga perbaikan yang dilakukan kurang memperhatikan dampak yang diberikan pada kinerja departemen lainnya. Oleh karena itu, pengukuran yang terintegrasi diperlukan oleh PT. MML yang mampu mengukur kinerja perusahaan untuk keseluruhan aspek dan melibatkan keseluruhan departemen serta mampu mengidentifikasi sasaran strategis yang diperlukan oleh perusahaan. 
Metode Balanced Scorecard dalam pengukuran kinerja perusahaan mampu melakukan pengukuran kinerja yang terintegrasi untuk seluruh departemen perusahaan. Menurut Kaplan dan Norton (1996), metode pengukuran Balanced Scorecard mencakup empat perspektif yaitu perspektif keuangan, perspektif pelanggan, perspektif proses bisnis internal dan perspektif pembelajaran dan pertumbuhan. Balanced Scorecard dapat membantu perusahaan untuk mengidentifikasi sasaran-sasaran strategis perusahaan berdasarkan visi misi perusahaan dan membentuk kerangka pengukuran untuk masing-masing perspektif.

Menurut Schneiderman (1999), metode Balanced Scorecard memiliki kelemahan dalam membentuk kerangka pengukuran kinerja antara lain penetapan ukuran kinerja dan pemacu kinerja pada kerangka pengukuran kinerja yang dilakukan secara subjektif. Hal ini dikarenakan metode Balanced Scorecard tidak memiliki guideline yang jelas dalam menentukan atau memilih ukuran kinerja dan pemacu kinerja. Penentuan ukuran kerja secara subjektif akan mempengaruhi gambaran mengenai permasalahan sesungguhnya yang dihadapi oleh perusahaan dan tindakan evaluasi yang dilakukan.

Menurut Koo (1998), untuk menghindari pengukuran yang subjektif, digunakanlah metode Quality Function Deployment (QFD) untuk dapat menentukan ukuran kinerja dan pemacu kinerja secara objektif. Menurut Yazdi dan Mennatib (2011), penentuan ukuran kinerja dan pemacu kinerja dengan metode Quality Function Deployment dilakukan dengan menggunakan matriks House of Quality yang didasari atas Voice of Customer dan Voice of Staff dimana secara tidak langsung dengan penggunaan metode ini, maka penetapan ukuran kinerja dan pemacu kinerja dilakukan oleh pihak-pihak terkait dan bukan hanya ditentukan oleh direktur semata. Tahapan matriks II pada metode QFD digunakan dalam perancangan peta strategi dan diagram sebab akibat. Metode QFD dalam perancangan kerangka pengukuran kinerja perusahaan tidak hanya mampu membantu dalam menentukan ukuran kinerja dan pemacu kinerja saja, namun juga menentukan prioritas terpenting atas ukuran kinerja dan pemacu kinerja yang digunakan dalam kerangka pengukuran Balanced Scorecard serta dalam perancangan diagram sebab akibat.

Dengan menggabungkan metode Balanced Scorecard dan metode Quality Functiion Deployment dalam perancangan kerangka pengukuran kinerja, diharapkan mampu membuat kerangka pengukuran kinerja yang tidak hanya mencakup keseluruhan perspektif, namun juga kerangka pengukuran kinerja yang objektif. Selain itu, pengukuran kinerja yang dilakukan pada tiap departemen perusahaan tidak lagi bersifat parsial namun dapat bergerak sinergis sesuai dengan visi misi perusahaan.

Berdasarkan latar belakang, maka penelitian ini bertujuan untuk melakukan perancangan kerangka pengukuran kinerja Balanced Scorecard dengan metode Quality Function Deployment dalam menentukan ukuran kinerja dan pemacu kinerja serta perancangan peta strategi dan diagram sebab akibat pada PT. MML.

\section{METODE PENELITIAN}

Metodologi penelitian merupakan langkah-langkah yang ditempuh dalam penelitian untuk mempermudah dalam memecahkan dan menganalisis masalah yang dihadapi. Penelitian ini dilaksanakan dalam beberapa tahap yaitu: (1) Penelitian pendahuluan, dilakukan pengamatan dan wawancara dengan pihak-pihak yang terkait seperti direktur dan beberapa manajer untuk mendapatkan pandangan umum perusahaan, data kinerja perusahaan dan untuk mengetahui pengukuran kinerja yang sedang diterapkan saat ini. (2)Identifikasi masalah dan perumusan masalah, yaitu pengukuran kinerja perusahaan yang masih bersifat parsial, (3)Tinjauan pustaka dilakukan untuk mencari literatur dalam menunjang berlangsungnya penelitian, (4)Tujuan penelitian, yaitu merancang kerangka pengukuran kinerja Balanced Scorecard dengan metode Quality Function Deployment yang menggunakan matriks House of Quality dalam menentukan ukuran kinerja dan pemacu kinerja serta matriks tahap II QFD dalam merancang peta strategi dan diagram sebab akibat, (5)Pengumpulan data berupa data umum perusahaan dan data pengukuran kinerja perusahaan saat ini, (6)Perancangan kerangka Balanced Scorecard dilakukan dengan pengidentifikasian visi misi perusahaan ke dalam empat perspektif, penetapan atribut ukuran kinerja dan pemacu kinerja untuk komponen kuesioner yang ditujukan untuk Top Manager, konsumen dan staf; Perancangan matriks House of Quality untuk perangkaian ukuran kinerja dengan pemacu kinerjanya, penetapan target, sasaran strategi, ukuran hasil dan pemacu kinerja pada keempat perspektif dan matriks QFD tahap II untuk merancang peta strategi dan diagram

JIM, Vol. 3, No. 2, Juli 2018, pp.89-100 
sebab akibat, (7)Simulasi dengan kerangka pengukuran kinerja Balanced Scorecard, (8) Kesimpulan dan saran dirangkum berdasarkan hasil penelitian yang dilakukan. Diagram alir metode penelitian dapat dilihat pada gambar 1 .

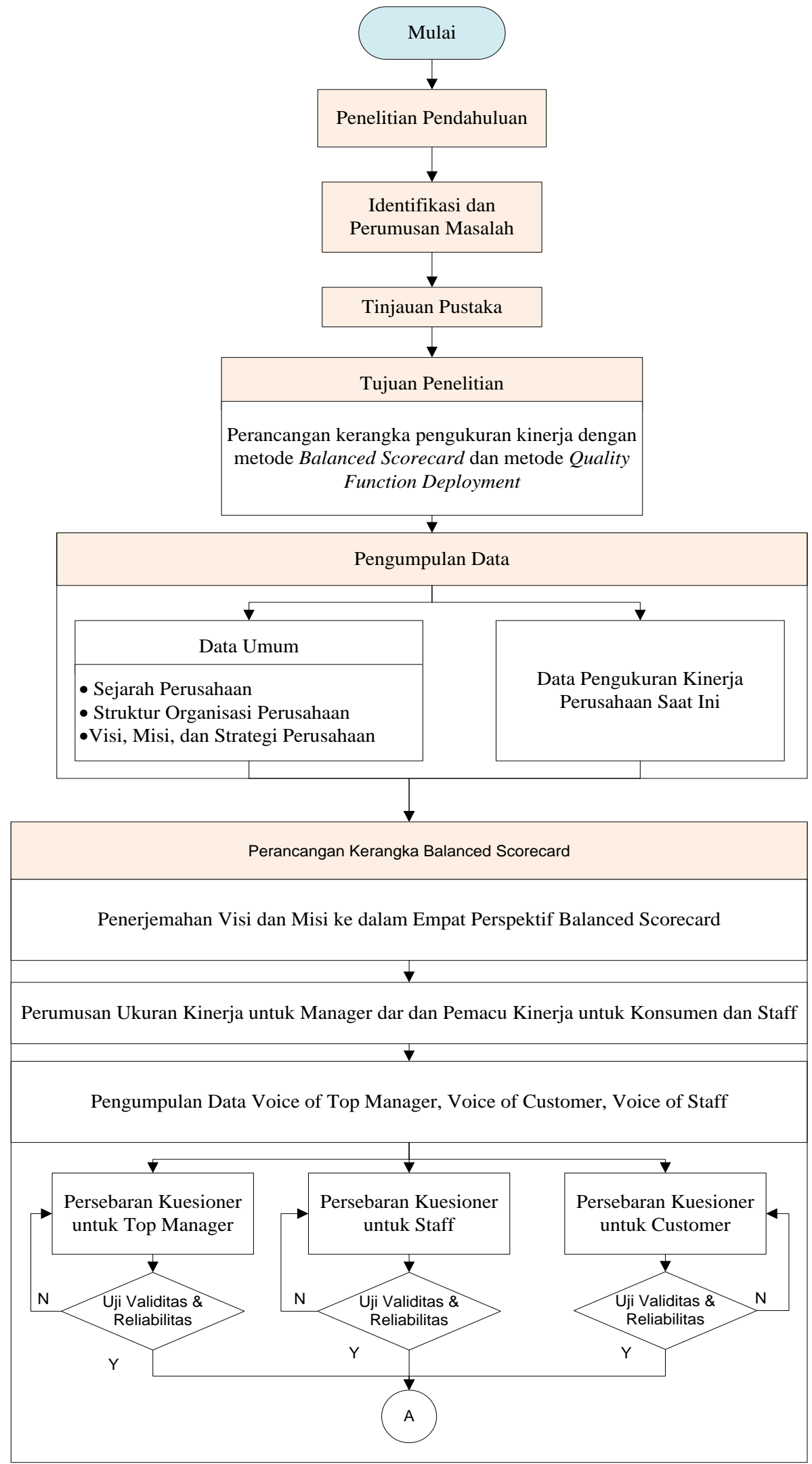

Gambar 1. Diagram Alir Metode Penelitian 


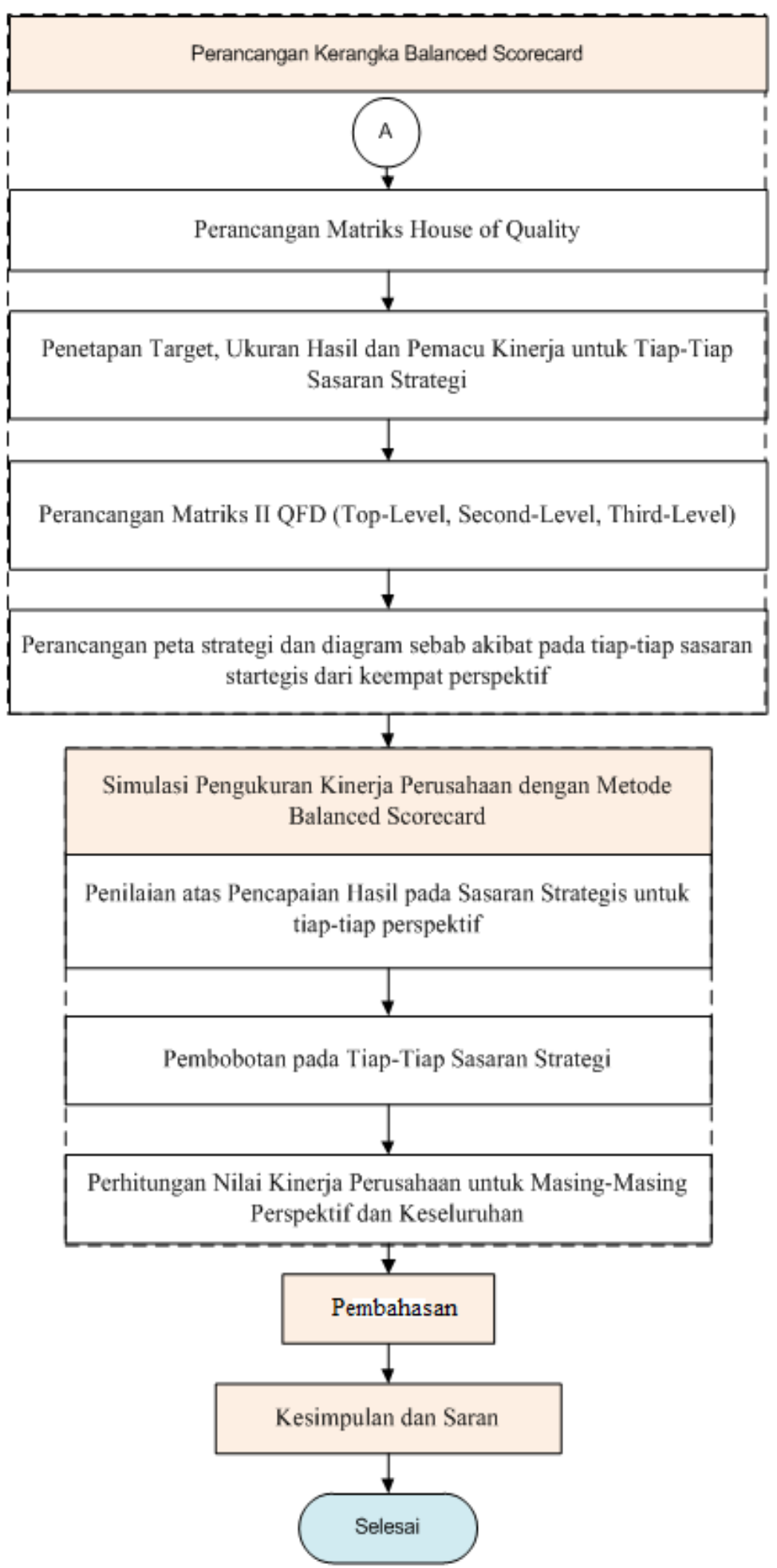

Gambar 1. Diagram Alir Metode Penelitian (Lanjutan) 


\section{HASIL DAN PEMBAHASAN}

\section{Pengukuran Kinerja Perusahaan Saat Ini}

PT. MML memiliki tiga departemen besar diantaranya departemen keuangan, departemen pergudangan dan departemen pelayanan. Masing-masing departemen memiliki sasaran strategi dengan ukuran kinerja dan pemacu kinerjanya. Hanya saja, ukuran kinerja dan pemacu kinerja yang diterapkan oleh tiap-tiap departemen tidaklah bekerja secara sinergis dengan departemen lain. Tiap-tiap departemen hanya berdiri sendiri-sendiri dalam mencapai sasaran strategi masingmasing departemen. Selain itu, pengukuran yang dilakukan oleh tiap-tiap departemen belumlah mencakup banyak aspek, mengingat perusahaan ini perusahaan muda yang masih perlu dibenahi.

Departemen keuangan memiliki dua sasaran strategis yaitu untuk meningkatan jumlah pendapatan dan meminimalisasi jumlah pengeluaran biaya. Ukuran kinerja yang digunakan adalah persentase jumlah pendapatan dan persentase jumlah pengeluaran biaya. Pemacu kinerja yang digunakan untuk sasaran strategis dalam meningkatkan jumlah pendapatan dengan meningkatkan persebaran segmen pasar. Pemacu kinerja yang digunakan untuk sasaran strategis dalam meminimalisasi pengeluaran biaya dengan melakukan penghematan semaksimal mungkin atas semua tindakan operasional.

Untuk departemen pergudangan, hanya ada satu sasaran strategi, yaitu mampu mengirim produk dengan tepat waktu. Ukuran kinerja yang digunakan adalah banyaknya jumlah keluhan dari konsumen akibat keterlambatan pengiriman produk. Pemacu kinerja yang digunakan adalah dengan menambah fasilitas transportasi untuk pengiriman produk seperti motor, atau mobil.

Departemen pelayanan memiliki satu sasaran strategi yaitu mendapatkan potongan harga terbaik dari supplier. Ukuran kinerja yang digunakan adalah mengukur jumlah pembelian barang ke supplier. Pemacu kinerjanya adalah meningkatkan penjualan dengan memberikan kualitas pelayanan terbaik untuk konsumen seperti kebenaran informasi yang diberikan ke konsumen seperti informasi harga, tipe produk, keramahan dan kesopanan karyawan dan menjalin hubungan baik dengan supplier.

Seluruh sasaran strategi yang ditetapkan beserta dengan ukuran kinerja dan pemacu kinerja pada departemen pelayanan dan pergudangan ditujukan untuk memacu pencapaian hasil kinerja pada perspektif keuangan. Hanya saja, ada pemacu kinerja yang dimiliki oleh departemen yang tidak mendukung pencapain kinerja keuangan, namun hanya memacu pencapaian hasil kinerja pada departemen itu sendiri. Pemacu kinerja seperti penambahan fasilitas transportasi pada departemen pergudangan tidak mendukung pencapaian kinerja pada departemen keuangan untuk meminimalisasi pengeluaran biaya. Masih ada solusi lain yang bisa digunakan sebagai pemacu kinerja yang mampu mendukung sasaran strategi dalam meminimalisasi pengeluaran biaya namun tetap dapat mencapai sasaran strategis departemen pergudangan untuk mampu mengirim produk dengan tepat waktu, seperti pengaturan sistem rute pengiriman produk ke konsumen, kecepatan dalam pengambilan produk, penataan produk yang baik di gudang untuk mempermudah pencaharian produk. Pemecahan permasalahan yang dihadapi oleh departemen pergudangan, hanya terpacu pada satu sudut pandang yaitu jumlah transportasi, dan belum menuntaskan akar dari permasalahan. Akar permasalahan yang sesungguhnya berdasarkan hasil pengamatan lapangan adalah kurang tangkasnya pekerja dalam mempersiapkan barang, kemacetan yang cukup parah untuk kawasan bekasi dan juga penataan rute perjalanan yang belum baik.

Begitu juga untuk departemen pelayanan, dimana sasaran strategis yang diterapkan disini terfokus pada supplier karena potongan harga yang diberikan. Keberhasilan departemen pelayanan dalam mendapatkan potongan harga terbaik sebenarnya disebabkan kepuasan konsumen yang hanya terpuaskan oleh harga yang terjangkau dan departemen tidak memandangan kepuasan konsumen karena pelayanan yang baik, atau kesetian konsumen dan sebaginya. Departemen hanya terfokus pada hubungan baik dengan supplier tanpa memandang aspek kepuasan konsumen lainnya. Dari semua sasaran strategi, ukuran kinerja dan pemacu kinerja yang diterapkan oleh perusahaan, belum mampu mencakup banyak aspek lainnya yang sesungguhnya penting untuk kemajuan dan eksistensi perusahaan dimata konsumen. Aspek lainnya itu seperti aspek kesetiaan konsumen, persebaran pangsa pasar, kesejahteraan karyawan dan masih banyak lainnya.

\section{Perancangan Kerangka Balanced Scorecard}

Pada bagian ini dilakukan perancangan kerangka pengukuran kinerja dengan dan metode Quality Function Deployment. Terdapat beberapa tahap dalam merancang kerangka ini. Tahap 
awal adalah dengan menerjemahkan visi misi ke empat perspektif, kemudian perumusan ukuran kinerja untuk manajer dan pemacu kinerja untuk pelanggan dan staf. Selanjutnya, dilakukan pengumpulan Voice of Top Manager, Voice of Customer dan Voice of Staff dan dilakukan uji validasi dan reliabilitas dari data yang ada lalu dilakukan perhitungan bobot untuk atribut ukuran kinerja atau pemacu kinerja. Perancangan matriks House of Quality yang dapat dilihat pada gambar 4 dilakukan untuk menentukan pemacu kinerja untuk ukuran kinerja, kemudian dilakukan perancangan kerangka Balanced Scorecard. Target yang ditetapkan dalam kerangka tersebut didapat dari hasil wawancara dengan direktur. Penetapan sasaran strategis, ukuran kinerja, pemacu kinerja dan target untuk tiap-tiap strategi untuk keempat perspektif dapat dilihat pada tabel 1 sebagai Kerangka Pengukuran Balanced Scorecard. Matriks QFD tahap II yang terdiri atas matriks Top Level, matrik Second Level, dan matriks Third Level digunakan untuk merancang peta strategi pada gambar 2 dan diagram sebab akibat dalam menentukan hubungan keterkaitan antar sasaran strategis pada gambar 3 .

\section{Simulasi}

Berdasarkan kerangka kinerja Balanced Scorecard dilakukan simulasi untuk mengetahui hasil pencapaian kinerja perusahaan untuk tahun 2011 yang dibandingkan dengan target pada kerangka pengukuran. Secara keseluruhan, target yang ditetapkan oleh direktur perusahaan untuk seluruh sasaran strategis cukuplah tinggi. Hal itu diakibatkan karena direktur ingin memberikan standar yang tinggi pada setiap hasil kinerja agar memiliki motivasi lebih dalam mencapai kinerja dengan hasil yang sempurna. Standar yang tinggi yang ditetapkan oleh direktur disesuaikan juga dengan kondisi perusahaan, kemampuan perusahaan dan kondisi persaingan pasar. Penilaian pencapaian sasaran strategi digunakan skala Likert. Selain itu, penentuan bobot sasaran strategi dilakukan dengan matriks hubungan dilakukan untuk mengetahui besarnya pengaruh masingmasing sasaran strategis dalam pencapaian kinerja pada perspektif keseluruhan. Selanjutnya, hasil pencapaian kinerja perusahaan dengan bobotnya, maka dihitung nilai kinerja untuk masing-masing perspektif.

Berdasarkan hasil kuesioner yang didapat, ditentukan pula bobot kepentingan perspektif bagi perusahaan yaitu perspektif keuangan dengan bobot 0,27 , dan perspektif pelanggan dan proses bisnis internal dengan bobot 0,25 serta perspektif pembelajaran dan pertumbuhan dengan bobot 0,23. Maka, pencapaian kinerja untuk perspektif keuangan adalah 3,1 yang tergolong cukup baik, perspektif pelanggan dengan nilai 3,51 yang tergolong baik. Pencapaian kinerja untuk proses bisnis internal mendapatkan bobot 4,27 dengan nilai sangat baik dan perspektif pembelajaran dan pertumbuhan mendapatkan bobot 4,33 yang juga tergolong sangat baik. Secara keseluruhan, dengan menggunakan kerangka pengukuran kinerja Balanced Scorecard, pencapaian nilai kinerja untuk perusahaan yang mencakup keseluruhan perspektif adalah sebesar 3,79 yang tergolong baik.

\section{KESIMPULAN}

Berdasarkan pengumpulan data, pengolahan data dan pembahasan data yang dilakukan dalam perancangan kerangka pengukuran kinerja Balanced Scorecard dengan metode Quality Function Deployment, maka dapat diambil kesimpulan berikut ini:

1. Dalam merancang kerangka pengukuran kinerja Balanced Scorecard, metode Quality Function mampu digunakan untuk penentuan ukuran kinerja dengan pemacu kinerjanya dan juga mampu merancang diagram sebab akibat dan peta strategi untuk PT. MML. Selain itu juga, telah dilakukan simulasi pengukuran kinerja dengan kerangka pengukuran untuk tahun 2011.

2. Dalam kerangka Balanced Scorecard, terdapat beberapa sasaran strategis baru yang mencakup keempat perspektif Balanced Scorecard seperti 4 sasaran strategis baru pada perspektif pelanggan, 5 sasaran strategis baru pada perspektif proses bisnis internal dan 3 sasaran strategis baru pada perspektif pembelajaran dan pertumbuhan.

3. Terdapat 3 sasaran strategis pada pengukuran kinerja sebelumnya yang digunakan kembali ke dalam kerangka Balanced Scorecard, yaitu meningkatkan pendapatan perusahaan dan meminimalisasi pengeluaran biaya pada perspektif keuangan dan ketepatan waktu dalam pengiriman produk pada perspektif pelanggan.

4. Terdapat 22 pemacu kinerja baru dalam kerangka pengukuran Balanced Scorecard dan 1 pemacu kinerja sebelumnya yang digunakan kembali.

JIM, Vol. 3, No. 2, Juli 2018, pp.89-100 
5. Berdasarkan hasil perhitungan pada matriks House of Quality, pemacu kinerja dalam pelatihan karyawan memiliki nilai yang paling tinggi yaitu $14,43 \%$ dan menjadi pemacu kinerja yang menjadi priotitas pertama dan diprioritas ke dua adalah pemacu kinerja dalam jalinan komunikasi yang baik dengan pihak manajer dengan nilai 12,88\%, prioritas ke tiga adalah pemacu kinerja dalam ketepatan pengiriman produk ke pelanggan mendapatkan nilai $8,49 \%$.

6. Berdasarkan hasil pencapaian sasaran strategis, secara keseluruhan, sasaran strategis pada seluruh perspektif rata-rata tergolong baik hanya saja untuk sasaran strategis dalam mengurangi nilai produk yang hilang memiliki nilai 1 yang tergolong sangat tidak baik. Hal ini perlu diperhatikan dengan memperhatikan pemacu kinerja untuk sasaran strategis tersebut yaitu menciptakan lingkungan kerja yang aman dengan memasang fasilitas seperti CCTV atau penambahan pintu besi untuk gudang, dan menjalin komunikasi yang baik dengan pekerja.

7. Perancangan Matriks QFD tahap II menghasilkan kembali prioritas sasaran-sasaran strategis untuk tiap-tiap perspektif. Untuk matriks Top-Level, sasaran strategis dalam memuaskan pelanggan menjadi prioritas utama, untuk matriks Second-Level, sasaran strategis yang menjadi prioritas utama adalah peningkatan variasi produk dan untuk matriks Third-Level adalah peningkatan keahlian karyawan dengan pemberian pelatihan.

8. Perancangan kerangka pemgukuran kinerja Balanced Scorecard dilakukan terhadap empat perspektif dengan bobot kepentingan yang berbeda. Perspektif keuangan dengan bobot kepentingan sebesar 0.27 , perspektif pelanggan sebesar 0.25 , perspektif proses bisnis internal sebesar 0.25 dan perspektif pembelajaran dan pertumbuhan sebesar 0.23. Perspektif keuangan dipandang memiliki kepentingan sedikit lebih penting dibandingkan perspektif lainnya.

9. Berdasarkan hasil perhitungan pencapaian kinerja, nilai kinerja untuk perspektif keuangan adalah 3,1 yang berarti cukup baik. Nilai kinerja untuk perspektif pelanggan adalah 3,51 dan nilai kinerja untuk perpektif proses bisnis internal adalah 4,27 tergolong kategori baik. Untuk nilai perspektif pembelajaran dan pertumbuhan adalah 4,33 yang berarti sangat baik. Berdasarkan nilai kinerja untuk tiap-tiap perspektif, nilai kinerja keseluruhan PT. MML adalah sebesar 3,79 yang tergolong baik.

\section{SARAN}

Berikut ini adalah beberapa saran yang diberikan untuk PT. MML khusunya berdasarkan penelitian yang telah dilakukan:

1. Menggunakan data primer. Dengan membiasakan tiap departemen untuk mencatat setiap kejadian dengan baik setiap bulannya. Sistem pendataan harus sebaik mungkin agar pengukuran dilakukan dapat akurat dan benar-benar mencerminkan hasil pencapaian kinerja perusahaan.

2. Menentukan pihak yang bertanggung jawab atas pengukuran kerangka kinerja Balanced Scorecard yang dilakukan serta mengawasi berjalannya aktifitas perusahaan.

3. Diagram sebab akibat dan prioritas pemacu kinerja pada matriks House of Quality dapat menjadi salah satu pertimbangan pengambilan keputusan untuk pemecahan masalah.

4. Perlu dilakukan penyesuaian target untuk seluruh sasaran strategis pada kerangka Balanced Scorecard setiap tahunnya

5. Saran yang dapat diberikan untuk penelitian berikutnya adalah penelitian berikutnya dapat melakukan penelitian dalam mengembangkan metode Balanced Scorecard sebagai sistem manajemen strategis dengan menggabungkan metode bantuan lainnya seperti SWOT. 


\section{DAFTAR PUSTAKA}

Bergen, C.W.Von and Daniel C. Benco. "A Balanced Scorecard for Small Business". USASBE Online .Home page on-line. Available from http://usasbe.org/knowledge/proceedings/proceedingsDocs/USASBE2004proceedingsVonbergen.pdf ; Internet; accessed 14 Februari 2012

Ciptani, Monika Kussetya. "Balanced Scorecard Sebagai Pengukuran Kinerja Masa Depan: Suatu Pengantar". Jurnal Akuntansi dan Keuangan Vol 2, no.1 (Mei 2000): 21-35

Cohen, Lou. 1995. Quality Function Deployment “How to Make QFD Work for You”. New York: Addison-Wesley Publishing Company.

Cohen, Yuval. "A new technique for evaluating the balanced scorecard". Problems and Perspectives in Management Vol.9/1 (2011): 78-84

Kaplan, Robert S. and David P. Norton. 2000. "Having Trouble with Your Strategy? Then Map It". Harvard Business School Review.

Kaplan, Robert S. and David P. Norton. 1996. The Balanced Scorecard: Translating Strategy Into Action. Boston-Massachusetts: Harvard Business School Press.

Koo, L. C. "Building Balanced Scorecard on the House of Quality". Industrial Engineering and Management (IEM) Symposium "Transformational Strategy Towards the 21st Century" Vol.1 (1998): 20-21

Kristina, Helena J. "Konsep Balanced Scorecard dalam Pengukuran Kinerja Suatu Organisasi”. Jurnal Teknik Industri Vol.2/2004

Mulyadi. 2005. "Sistem Manajemen Strategic Berbasis Balanced Scorecard”. Yogyakarta: UPP AMP YPKN.

Schneiderman, Arthur.M. "Why Balanced Scorecards Fail". Journal of Strategic Performance Measurement (Januari 1999)

Sinha, Abhijit. "Balanced Scorecard: A Strategic Management Tool". Vidyasagar University Journal of Commerce Vol. 11 (Maret 2006): 71-81

Yazdi, Amir Karbassi dan Bahman Mennatib. "House of Excellence: Better BSC Practice Through QFD Plus Hoshin Kanri”. Australian Journal of Basic and Applied Sciences Vol.5/6 (2011): 1151-1159

Yuwono, Sony, Edy Sukarno, dan Muhammad Ichsan. Petunjuk Praktis Penyusunan Balanced Scorecard; Menuju Organisasi yang Berfokus pada Strategi. $4^{\text {th }}$. Jakarta: PT. Gramedia Pustaka Utama, 2006. 


\section{Lampiran}

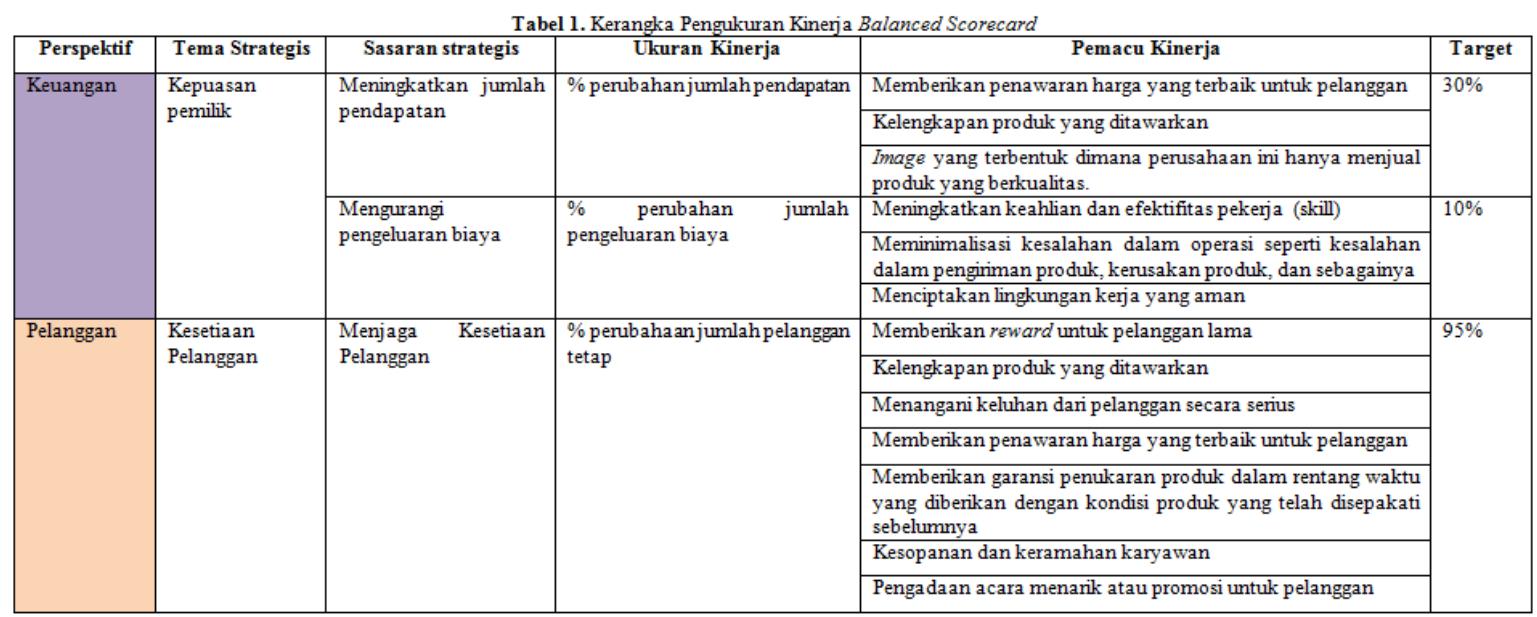

\begin{tabular}{|c|c|c|c|c|c|}
\hline Perspektif & Tema Strategis & Sasaran strategis & Ukuran Kinerja & Pemacu Kinerja & Target \\
\hline \multirow[t]{15}{*}{ Pelanggan } & \multirow[t]{11}{*}{$\begin{array}{l}\text { Kepuasan } \\
\text { Pelanggan }\end{array}$} & \multirow[t]{4}{*}{$\begin{array}{l}\text { Meningkatkan } \\
\text { kepuasan pelayanan }\end{array}$} & \multirow[t]{4}{*}{ Jumlah komplain yang diterima } & $\begin{array}{l}\text { Memberikan garansi penukaran produk dalam rentang waktu } \\
\text { yang diberikan dengan kondisi produk yang telah disepakati } \\
\text { sebelumnya }\end{array}$ & \multirow[t]{4}{*}{0} \\
\hline & & & & Menangani keluhan dari pelanggan secara serius & \\
\hline & & & & Keramahan dan kesopanan karyawan & \\
\hline & & & & Pelatihan karyawan & \\
\hline & & \multirow{3}{*}{$\begin{array}{l}\text { Mengurangi } \\
\text { keterlambatan } \\
\text { pengiriman }\end{array}$} & \multirow{3}{*}{$\begin{array}{l}\text { Jumlah keluhan akibat } \\
\text { keterlambatan pengiriman }\end{array}$} & Meningkatkan keahlian pekerja & \multirow[t]{3}{*}{0} \\
\hline & & & & Komunikasi yang baik di dalam organisasi & \\
\hline & & & & Ketepatan dalam pengiriman produk & \\
\hline & & \multirow[t]{4}{*}{$\begin{array}{l}\text { Memberikan nilai lebih } \\
\text { untuk pelanggan }\end{array}$} & \multirow[t]{4}{*}{$\begin{array}{l}\text { Jumlah acara menarik untuk } \\
\text { pelanggan }\end{array}$} & $\begin{array}{l}\text { Meningkatkan skill pekerja untuk melakukan inovasi atas ide } \\
\text { acara }\end{array}$ & \multirow[t]{4}{*}{8} \\
\hline & & & & $\begin{array}{l}\text { Melaksanakan acara promosi khusus untuk wilayah tertentu dan } \\
\text { pelanggan perusahaan saja }\end{array}$ & \\
\hline & & & & Kesopanan dan keramahaan karyawan & \\
\hline & & & & Memberikan jaminan penawaran harga yang baik & \\
\hline & \multirow{4}{*}{$\begin{array}{l}\text { Akuisisi } \\
\text { Pelanggan }\end{array}$} & \multirow{4}{*}{$\begin{array}{l}\text { Meningkatkan pangsa } \\
\text { pasar }\end{array}$} & \multirow[t]{4}{*}{ Jumlah pelanggan baru } & Mengikuti pameran-pameran di luar dan di dalam bekasi & \multirow[t]{4}{*}{15} \\
\hline & & & & Penawaran harga yang memuaskan & \\
\hline & & & & Kelengkapan produk & \\
\hline & & & & Hanya menjual produk berkualitas & \\
\hline \multirow{3}{*}{$\begin{array}{l}\text { Proses Bisnis } \\
\text { Intemal }\end{array}$} & \multirow[t]{3}{*}{ Proses inovasi } & \multirow{3}{*}{$\begin{array}{l}\text { Kelengkapan produk } \\
\text { yang ditawarkan }\end{array}$} & \multirow{3}{*}{$\begin{array}{lr}\text { Jumlah } & \text { pertambahan } \\
\text { keanekaragaman } & \text { produk } \\
\text { (Variasi produk) } & \end{array}$} & Komunikasi yang baik dengan pihak manajerial & \multirow[t]{3}{*}{20} \\
\hline & & & & Kepercayaan yang diberikan oleh atasan & \\
\hline & & & & Pelaksanaan pelatihan & \\
\hline
\end{tabular}




\begin{tabular}{|c|c|c|c|c|c|}
\hline Perspektif & Tema Strategis & Sasaran strategis & Ukuran Kinerja & Pemacu Kinerja & Target \\
\hline \multirow{13}{*}{$\begin{array}{l}\text { Proses Bisnis } \\
\text { Internal }\end{array}$} & \multirow[t]{9}{*}{ Proses operasi } & \multirow{2}{*}{$\begin{array}{l}\text { Mengurangi produk } \\
\text { yang hilang }\end{array}$} & \multirow[t]{2}{*}{ Nilai produk yang hilang } & Menciptakan lingkungan kerja yang aman & \multirow[t]{2}{*}{0} \\
\hline & & & & Menjalin komunikasi yang baik dengan pekerja & \\
\hline & & \multirow[t]{3}{*}{$\begin{array}{l}\text { Mengurangi kelalaian } \\
\text { dalam pengiriman } \\
\text { produk }\end{array}$} & \multirow[t]{3}{*}{$\begin{array}{l}\text { Jumlah kesalahan produk dalam } \\
\text { pengiriman }\end{array}$} & $\begin{array}{l}\text { Komunikasi yang baik di dalam organisasi untuk mampu } \\
\text { meningkatkan ketepatan atau ketelitian dalam pengiriman } \\
\text { produk sesuai dengan permintaan pelanggan }\end{array}$ & \multirow[t]{3}{*}{0} \\
\hline & & & & Memanfaatkan fasilitas teknologi & \\
\hline & & & & Ketepatan dan ketelitian dalam pengiriman produk & \\
\hline & & \multirow{4}{*}{$\begin{array}{l}\text { Persebaran pangsa } \\
\text { pasar }\end{array}$} & \multirow{4}{*}{$\begin{array}{l}\text { Jumlah stand atau pameran } \\
\text { yang dilaksanakan }\end{array}$} & Pelaksanaan pelatihan staf untuk lebih kreatif & \multirow[t]{4}{*}{8} \\
\hline & & & & Komunikasi yang baik dengan pihak manajerial & \\
\hline & & & & Hanya menjual produk berkualitas dan ternama & \\
\hline & & & & Penawaran harga yang memuaskan & \\
\hline & \multirow{4}{*}{$\begin{array}{l}\text { Proses pelayanan } \\
\text { purna jual }\end{array}$} & \multirow{4}{*}{$\begin{array}{l}\text { Meningkatkan } \\
\text { penanganan komplain }\end{array}$} & \multirow{4}{*}{$\begin{array}{l}\text { \% jumlah komplain yang } \\
\text { tertangani }\end{array}$} & Keseriusan dalam pelatihan skill pekerja & \multirow[t]{4}{*}{$95 \%$} \\
\hline & & & & $\begin{array}{l}\text { Pemberian penghargaan atas keberhasilan penanganan } \\
\text { masalah }\end{array}$ & \\
\hline & & & & Pelatihan skill pekerja & \\
\hline & & & & Komunikasi yang baik dengan pihak manajerial & \\
\hline \multirow{6}{*}{$\begin{array}{l}\text { Pertumbuhan } \\
\text { dan } \\
\text { pembelajaran }\end{array}$} & \multirow{5}{*}{$\begin{array}{l}\text { Kapabilitas } \\
\text { pekerja }\end{array}$} & \multirow{3}{*}{$\begin{array}{l}\text { Meningkatkan } \\
\text { produktifitas karyawan }\end{array}$} & \multirow[t]{3}{*}{$\%$ absensi karyawan } & Kepuasan gaji pekerja & \multirow[t]{3}{*}{$10 \%$} \\
\hline & & & & Pemberian tunjangan & \\
\hline & & & & Komunikasi yang baik dengan pihak manajer & \\
\hline & & \multirow{2}{*}{$\begin{array}{l}\text { Meningkatkan keahlian } \\
\text { karyawan }\end{array}$} & \multirow[t]{2}{*}{$\%$ pelatihan karyawan } & Memberikan pelatihan bagi karyawan & \multirow[t]{2}{*}{$90 \%$} \\
\hline & & & & Pemberian penghargaan & \\
\hline & $\begin{array}{l}\text { Kepuasan } \\
\text { karyawan }\end{array}$ & $\begin{array}{l}\text { Memperkuat tali } \\
\text { persaudaraan }\end{array}$ & $\begin{array}{l}\text { Jumlah pelaksanaan acara } \\
\text { kebersaman }\end{array}$ & Dilaksanakan acara kebersamaan untuk pekerja & 4 \\
\hline
\end{tabular}

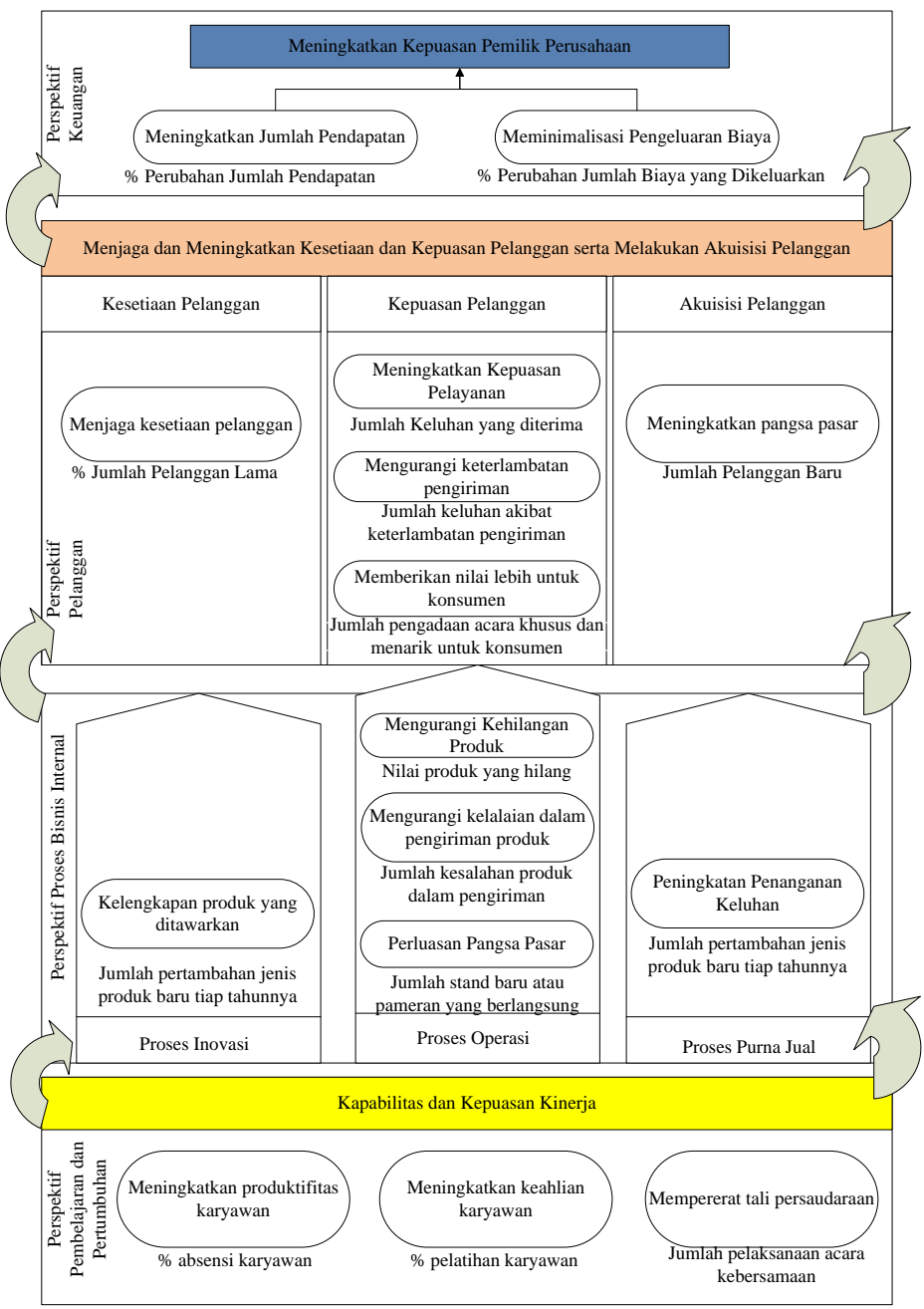

Gambar 2. Peta Strategi PT. MML

JIM, Vol. 3, No. 2, Juli 2018, pp.89-100 


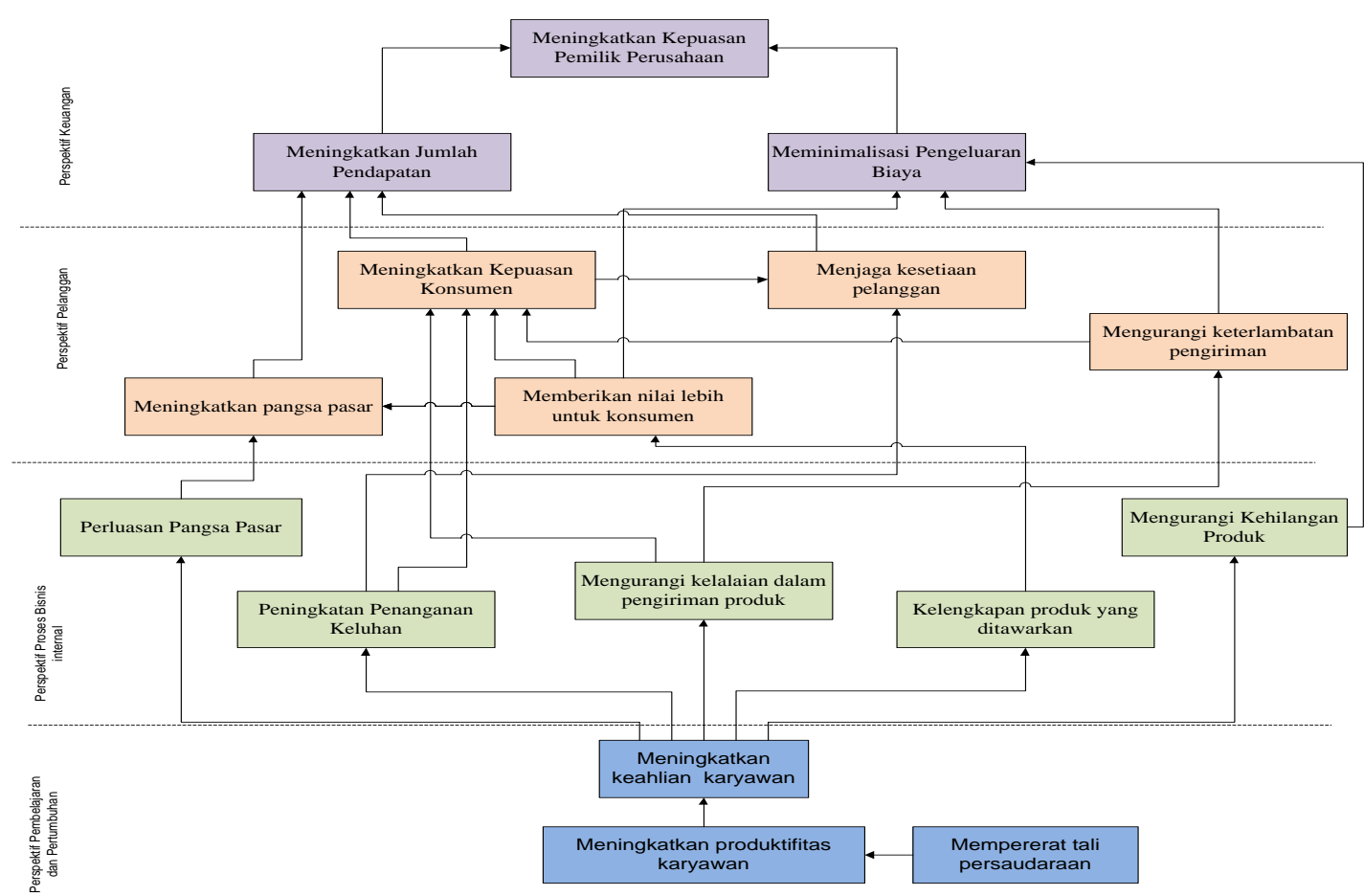

Gambar 3. Diagram Sebab Akibat antar Sasaran Strategis PT. MML 
